\title{
Pengaruh Pengalaman Prakerin, Konsep Diri Dan Komitmen Siswa Terhadap Kesiapan Kerja Bidang Otomotif Sekolah Menengah Kejuruan Di Kediri
}

\author{
Mohamad Alfin Hilmi ${ }^{1}$, Titik Winarti ${ }^{2}$, Eppy Yuandra ${ }^{3}$ \\ ${ }^{1,2,3}$ Pascasarjana Pendidikan Vokasi \\ (Universitas Negeri Surabaya)
}

e-mail: $\underline{\text { 1mohamad.19007@mhs.unesa.ac.id, }}, \underline{2}$ titiekwinanti@unesa.ac.id, ${ }^{3}$ eppyyundra@unesa.ac.id

\begin{abstract}
Abstrak
Penelitian yang dilaksanakan ini merupakan jenis penelitian expost facto. Tujuan penelitian ini adalah untuk mengetahui: (1) pengaruh pengalaman prakerin dengan konsep diri, (2) pengaruh pengalaman prakerin dengan komitmen siswa, (3) pengaruh pengalaman prakerin dengan kesiapan kerja, (4) pengaruh konsep diri dengan komitmen siswa, (5) pengaruh konsep diri dengan kesiapan kerja, (6) pengaruh komitmen siswa dengan kesiapan kerja, (7) pengaruh pengalaman prakerin, konsep diri, komitmen siswa dengan kesiapan kerja populasi pada penelitian ini adalah siswa teknik kendaraan ringan di Kediri yang berjumlah 90 siswa. Semua siswa dalam populasi menjadi responden pengambilan data. Pengumpulan data variabel pengalaman prakerin (X1), konsep diri (X2), komitmen siswa (X3), kesiapan kerja $(Y)$, menggunakan lembar angket. Data penelitian dianalisis dengan analisis jalur. Hasil penelitian: (1) terdapat pengaruh pengalaman prakerin dengan kesiapan kerja dengan presentase pengaruh terhadap kesiapan kerja 41,80 persen, (2) terdapat pengaruh konsep diri dengan kesiapan kerja dengan presentase pengaruh konsep diri terhadap kesiapan kerja 47,65 persen. (3) terdapat pengaruh komitmen siswa dengan kesiapan kerja dengan presentase pengaruh komitmen siswa terhadap kesiapan kerja 10,55 persen. (4) variabel konsep diri merupakan variabel yang paling berpengaruh pada kesiapan kerja dengan presentase tertinggi yaitu 46,65 persen.
\end{abstract}

Kata kunci: pengalaman praktik kerja industri, konsep diri, komitmen siswa, kesiapan kerja

\begin{abstract}
This research is a type of ex post facto research. The purpose of this study was to determine: (1) the effect of the experience of internship with self-concept, (2) the influence of experience of internship with student commitment, (3) the influence of experience of internship with work readiness, (4) the influence of self-concept with student commitment, (5) the influence of self-concept with work readiness, (6) the effect of student commitment to work readiness, (7) the influence of experience of internship, self-concept, student commitment to work readiness of the population in this study were light vehicle engineering students in Kediri totaling 90 students. All students in the population become respondents of data collection. Data collection of prakerin experience variables (X1), self-concept (X2), student commitment $(X 3)$, work readiness $(Y)$, using questionnaire sheets. Research data were analyzed by path analysis.The results of the study: (1) there is an effect of the experience of apprenticeship with work readiness with the percentage of influence on job readiness 41.80 percent, (2) there is an effect of self concept with work readiness with the percentage influence of self concept on work readiness 47.65 percent. (3) there is an influence of student commitment to work readiness with the percentage influence of student commitment to work readiness 10.55 percent. (4) the self-concept variable is the variable that most influences the work readiness with the highest percentage that is 46.65 percent.
\end{abstract}

Keywords: experience of industrial work practices, self-concept, student commitment, work readiness 


\section{Pendahuluan}

Indonesia merupakan salah satu negara dengan jumlah penduduk yang banyak. Kementerian Dalam Negeri mendata jumlah penduduk Indonesia terhitung 31 Desember 2015 mencapai 259.940.857. Jumlah ini terdiri atas 132.240.055 laki-laki dan 127.700 .802 perempuan. Jumlah penduduk Indonesia yang banyak itu, tidak menuntut kemungkinkan akan semakin banyak pula permasalahan yang ditimbulkannya. Salah satu permasalahan tersebut adalah menyempitnya lapangan pekerjaan yang mengakibatkan jumlah pengangguran semakin banyak.

Data Badan Pusat Statistik menyebutkan bahwa tingkat pengangguran terbuka tertinggi adalah untuk masyarakat lulusan sekolah menengah atas (SMA) dan sekolah menengah kejuruan (SMK) sebesar 10,66 persen dan 10,43 persen, sementara pengangguran lulusan sekolah dasar (SD) ke bawah jumlahnya 3,56 persen naik dari posisi Februari 2013, 3,37 persen. Pengangguran lulusan sekolah menengah pertama (SMP) mencapai 8,37 persen atau naik dari februari 2013 sebesar 7,83 persen. Pengangguran lulusan diploma I/II/III mencapai 7,16 persen atau turun dari februari 2013 sebesar 11,59 persen. Terakhir pengangguran lulusan universitas turun menjadi 8,02 persen dari 9,95 persen di februari 2013. Hal ini menunjukan bahwa siswa lulusan sekolah menengah kejuruan yang seharusnya merupakan tenaga siap pakai ternyata belum terbukti. Para lulusan sekolah menengah kejuruan justru terbanyak menjadi pengangguran. Masalah sosial seperti narkoba, kriminalitas, pergaulan bebas, premanisme, dan lain sebagainya akan timbul apabila masalah penganguran dibiarkan dan tidak segera ditanggulangai, kondisi tersebut juga akan mengganggu pembangunan disegala bidang dan stabilitas nasional.

Salah satu permasalahan pendidikan nasional yang hingga kini masih dihadapi bangsa Indonesia adalah rendahnya tingkat relevansi, di samping masalah mutu, pemerataan, efisiensi, dan efektivitas pendidikan. Setiap lulusan lembaga pendidikan baik formal maupun non formal akan terjun dalam masyarakat atau dunia kerja dan menghadapi dunia nyata dengan segala tuntutan dan prasyarat yang diperlukan agar dapat memainkan perannya dengan baik[1]. Tuntutan dan prasyarat tersebut terus mengalami perkembangan seiring dengan berkembangnya tuntutan kemajuan. Oleh karena itu, pendidikan dalam perencanaan, pengelolaan, dan pelaksanaannya harus senantiasa berorientasi pada lingkungan hidup yang selalu berubah.

Perkembangan ilmu pengetahuan dan teknologi serta tuntutan globalisasi secara bersama sama telah mengakibatkan persaingan yang semakin ketat dalam penyediaan sumber daya manusia yang unggul. Untuk dapat terus mempertahankan daya saingnya, sumber daya manusia yang ada dituntut untuk terus meningkatkan pengetahuan, keterampilan, sikap, dan nilai nilai atau kompetensinya, sehingga setiap orang harus mampu menjadi pembelajar sepanjang hayat [2]. Dengan tingkat kompetensi yang tinggi, seseorang akan memiliki fleksibilitas yang tinggi pula dalam menyikapi perubahan yang ada di sekitarnya, termasuk dalam pergaulan, dalam pekerjaan, maupun dalam organisasi.

Penyediaan sumber daya manusia yang unggul dapat dimulai sejak seseorang belajar di sekolah. Sekolah sebagai lembaga pendidikan formal memiliki peran penting dalam penyiapan lulusan sebagai tenaga kerja yang siap pakai sesuai dengan bidang dan jenjang pendidikannya. Disamping itu sekolah juga berperan dalam mempersiapkan peserta didik untuk mampu beradaptasi dengan lingkungannya. Harapan tersebut ternyata belum dapat terpenuhi sebagaimana mestinya, tingkat keterampilan dan kepribadian yang dimiliki para lulusan ternyata masih lemah dalam menghadapi tantangan kehidupan yang ada.

Sekolah menengah kejuruan merupakan lembaga pendidikan yang bertujuan menyiapkan peserta didiknya untuk menjadi tenaga kerja yang terampil dan mengutamakan kemampuan untuk melaksanakan pekerjaan tertentu. Hal ini sesuai dengan tujuan khusus yang ada dalam kurikulum tingkat satuan pendidikan yang menyebutkan bahwa, sekolah menengah kejuruan bertujuan untuk, (1) menyiapkan peserta didik agar menjadi manusia produktif, mampu bekerja mandiri, mengisi lowongan pekerjaan yang ada di dunia usaha dan dunia industri sebagai tenaga kerja tingkat menengah sesuai dengan kompetensi dalam program keahlian yang dipilihnya, (2) membekali peserta didik agar 
mampu memilih karier, ulet dan gigih dalam berkompetensi, beradaptasi di lingkungan kerja, dan mengembangkan sikap profesional dalam bidang keahlian yang diminatinya, (3) membekali peserta didik dengan ilmu pengetahuan, teknologi, dan seni agar mampu mengembangkan diri di kemudian hari baik secara mandiri maupun melalui jenjang pendidikan yang lebih tinggi, (4) membekali peserta didik dengan kompetensi kompetensi yang sesuai dengan program keahlian yang dipilih [3]. Lulusan sekolah menengah kejuruan seharusnya adalah sosok sosok yang mempunyai kemampuan untuk mengimplementasi kemampuan bekerja yang dimiliki anak didik. Sekolah memberikan pendidikan yang bersifat nyata atau langsung terjun ke dunia industri melalui praktik kerja industri untuk membekali anak didiknya agar siap kerja di industri. Praktik kerja industri adalah suatu bentuk penyelenggaraan pendidikan dan pelatihan keahlian kejuruan yang secara sistematik dan sinkron antara program pendidikan di sekolah dengan program penguasaan keahlian yang diperoleh melalui kegiatan bekerja langsung di dunia kerja [4].

Praktik kerja industri dilaksanakan untuk memenuhi kebutuhan tenaga kerja yang profesional dibidangnya, siswa yang melaksanakan pendidikan tersebut diharapkan dapat menerapkan ilmu yang didapat dan mempelajari ilmu yang ada di dunia industri [5]. Praktik kerja industri merupakan kegiatan pendidikan dan latihan kerja dengan mengembangkan kemampuan, keahlian, dan profesi ditempat kerja sesuai dengan bidang studi atau jurusan masing masing siswa. Pelaksanaan praktik kerja industri tersebut secara tidak langsung akan memberikan siswa pengalaman serta bekal pengetahuan dalam bekerja. Siswa diajarkan untuk bekerja dengan kemampuan sendiri supaya mereka mandiri sehingga mereka bisa mendapatkan prestasi yang sesuai dengan kemampuannya.

Prestasi pengalaman yang didapat dan dipahami dengan baik diharapkan akan menumbuhkan minat serta keinginan untuk bekerja pada dunia usaha atau dunia industri. Sekolah menengah kejuruan mendidik siswanya untuk menjadi manusia yang mampu mengaplikasikan ilmunya di dunia industri . Siswa akan dibekali dengan keterampilan dan ilmu ilmu yang bermanfaat dalam bidang mekanik otomotif dan dapat dikembangkan jika mereka tidak ingin melanjutkan ke perguruan tinggi mata pelajaran produktif teknik kendaraan ringan merupakan salah satu ciri muatan yang dibelajarkan pada kurikulum tingkat satuan pendidikan sekolah menengah kejuruan sekarang ini.

Terjadinya mismatch antara lulusan dengan dunia kerja yang terlihat dengan terus meningkatnya jumlah pengangguran tenaga terdidik tersebut merupakan cermin bahwa strategi dalam pembangunan sumber daya manusia masih perlu diperbaiki dan disempurnakan, tetapi tidak boleh terjebak pada kebijakan bahwa pendidikan semata mata hanya untuk memenuhi tuntutan dunia kerja. Jaya [6] menyatakan bahwa, tidak akan ada kemajuan pendidikan tanpa inovasi, pembaharuan pendidikan yang membawa ke arah kesuksesan memerlukan inovasi. Berdasarkan pendapat tersebut, untuk dapat menyediakan pendidikan yang sesuai dengan kebutuhan masyarakat diperlukan inovasi inovasi pendidikan, sehmgga diperoleh cara cara belajar yang baru, cara-cara belajar keterampilan dasar yang baik, cara cara mengelola sumber-sumber belajar, dan sebagainya. Sekolah menengah kejuruan merupakan salah satu institusi pendidikan yang secara khusus bertujuan mempersiapkan peserta didik agar siap bekerja, baik bekerja secara mandiri maupun mengisi lowongan pekerjaan yang ada.

\section{Metode Penelitian}

Jenis penelitian adalah penelitian kuantitatif expost facto merupakan penelitian yang bertujuan menemukan penyebab yang memungkinkan perubahan perilaku, gejala atau fenomena yang disebabkan oleh suatu peristiwa, perilaku atau hal hal yang menyebabkan perubahan pada variable bebas yang secara keseluruhan sudah terjadi. 
Dalam penelitian expost facto secara metodis merupakan penelitian eksperimen yang juga menguji hipotesis tetapi tidak memberikan perlakuan perlakuan tertentu karena sesuatu sebab kurang etis untuk memberikan perlakuan atau memberikan manipulasi. Biasanya karena alasan etika manusiawi, atau gejala peristiwa tersebut sudah terjadi dan ingin menelusuri factor faktor penyebabnyab atau hal hal yang mempengaruhinya. Dalam pengertian sederhana expost facto memiliki arti yaitu dari apa dikerjakan setelah pernyataan penelitian ini disebut sebagai penelitian sesudah kejadian. Penelitian ini juga sering disebut after the fact atau sesudah fakta dan ada pula peneliti yang menyebutnya sebagai retrospective study atau studi penelusuran kembali [7]. Penelitian expost facto merupakan penelitian dimana variabel variabel bebas telah terjadi ketika peneliti mulai dengan pengamatan variabel terikat dalamsuatupenelitian. Menurut Arikunto [8] juga menyatakan bahwa penelitian expot facto merupakan penemuan empiris yang dilakuakan secara sistematis, peneliti tidak melakukan kontrol terhadap variabel variabel bebas karena manifestasinya sudah terjadi.

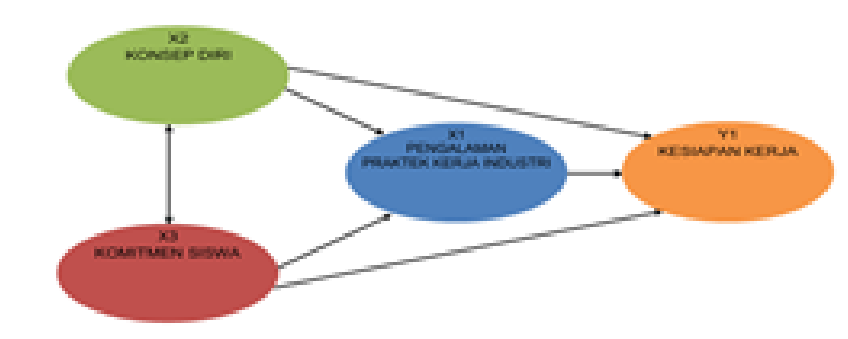

Gambar. Desain Penelitian

Keterangan:

$$
\begin{aligned}
& \mathrm{X} 1 \text { = Pengalaman praktik kerja industri } \\
& \quad \text { ( interveting variable) } \\
& \mathrm{X} 2 \text { = Konsep diri } \\
& \mathrm{X} 3=\text { komitmen siswa } \\
& \mathrm{Y}=\text { Kesiapan Kerja }
\end{aligned}
$$

Tempat dan Waktu Penelitian

Penelitian ini dilakukan pada SMK, yaitu SMK Negeri 1 Grogol kabupaten Kediri, SMK Ar rahmah Papar kabupaten Kediri dan SMK Al Huda Kota Kediri. Pemilihan ketiga sekolah tersebut karena komptensi keahlian teknik kendaraan ringan yang ada pada kedua SMK tersebut terakreditasi A, sedangkan DU/DI yang terpilih adalah Astra Toyota Auto 2000 Kediri, Astra Daihatsu, Astra Izusu dan Unitet Motor Center Suzuki Motor Kediri. Pelaksanaan penelitian dilakukan pada bulan Agustus 2019 sampai dengan Desember 2019.

\section{Analisis Data}

Analisis jalur adalah suatu teknik pengembangan dari regresi linier ganda. Teknik ini digunakan untuk menguji besarnya sumbangan (kontribusi) yang ditunjukkan oleh koefisien jalur pada setiap diagram jalur dari hubungan kausal antar variabel X1 X2 dan X3 terhadap Y serta dampaknya terhadap Z. Analisis jalur ialah suatu teknik untuk menganalisis hubungan sebab akibat yang tejadi pada regresi berganda jika variabel bebasnya mempengaruhi variabel tergantung tidak hanya secara langsung tetapi juga secara tidak langsung. Karakteristik analisis jalur adalah metode analisis data multivariat dependensi yang digunakan untuk menguji hipotesis hubungan asimetris yang dibangun atas dasar kajian teori tertentu, dengan tujuan untuk mengetahui pengaruh langsung dan tidak langsung seperangkat variabel penyebab terhadap variabel akibat. 
Menguji hipotesis hubungan asimetris yang dibangun atas kajian teori tertentu artinya yang diuji adalah model yang menjelaskan hubungan kausal antarvariabel yang dibangun atas kajian teori teori tertentu. Hubungan kausal tersebut secara eksplisit dirumuskan dalam bentuk hipotesis direksional, baik positif maupun negatif. Hubungan pengalaman prakerin konsep diri, komitmen siswa terhadap kesiapan kerja bidang otomotif sekolah menengah kejuruan oleh peneliti bisa diterjemahkan ke dalam sebuah diagram alur seperti:

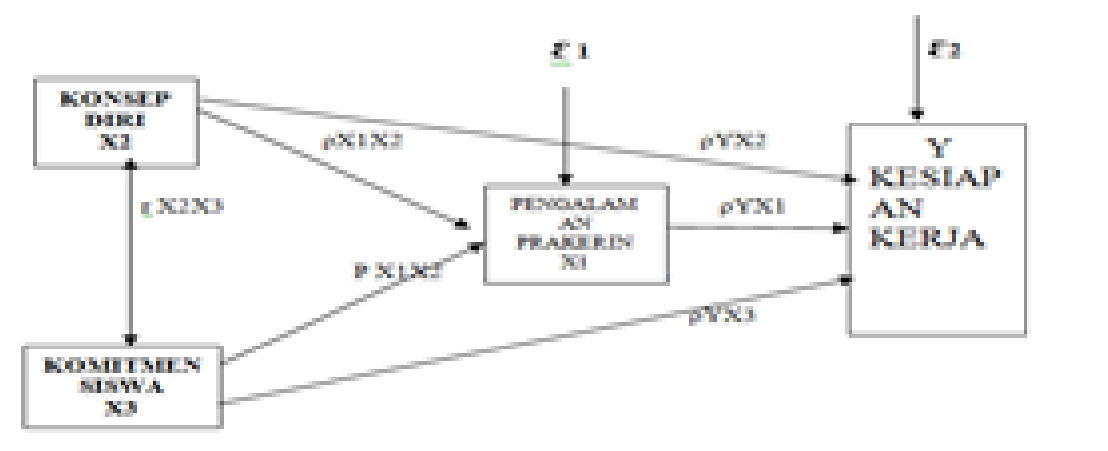

\section{Hubungan struktural antara X1, X2, X3 dan Y}

menyatakan bahwa diagram jalur hanya terdiri dari sebuah substruktur (yang juga merupakan struktur lengkapnya), yang berisi tiga buah variabel eksogen X1, X2, X3 dan sebuah variabel endogen, yaitu $\mathrm{Y}$, persamaan struktural untuk diagram jalur diatas adalah

$$
\mathrm{Y}=\rho \mathrm{YX} 1 \mathrm{X} 1+\rho \mathrm{YX} 2 \mathrm{X} 2+\rho \mathrm{YX} 3 \mathrm{X} 3+\varepsilon
$$

\section{Diskripsi Hasil Penelitian}

Pada bab ini diperoleh data data melalui angket pengalaman prakerin, konsep diri, komitmen siswa dan kesiapan kerja bidang otomotif sekolah menengah kejuruan di Kediri, selanjutnya akan dijadikan bahan perhitungan dalam penelitian ini. Hasil pengumpulan data masih dalam bentuk skor mentah. Untuk keperluan uji statistik terhadap data data penelitian, maka dari skor mentah tersebut diubah menjadi skor baku.

Deskripsi data dilakukan untuk memaparkan:

1. Data pengalaman prakerin,

2. Data konsep diri,

3. Data komitmen siswa,

4. Data kesiapan kerja.

\section{Data Skor Pengalaman Prakerin}

Data hasil penelitian pengalaman prakerin dilakukan intrumen angket pengalaman prakerin dengan cara meyebarkan angket pengalaman prakerin. 


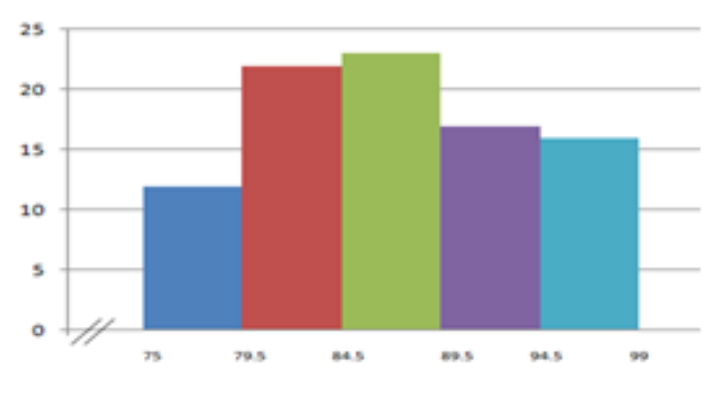

Hitogram data pengalaman prakerin

\section{Data Skor Konsep diri}

Data hasil penelitian pengalaman prakerin dilakukan intrumen angket konsep diri dengan cara meyebarkan angket konsep diri. Data pengalaman prakerin seperti yang tampak pada

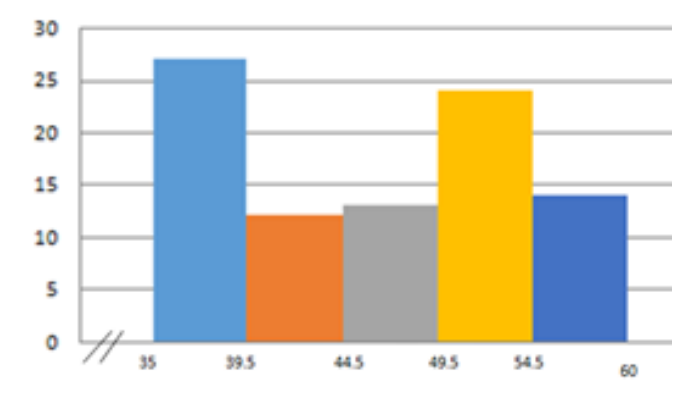

Gambar Hitogram data konsep diri

\section{Data Skor Komitmen Siswa}

Data hasil penelitian komitmen siswa dilakukan intrumen angket komitmen siswa dengan cara meyebarkan angket komitmen siswa. Data komitmen siswa seperti yang tampak pada

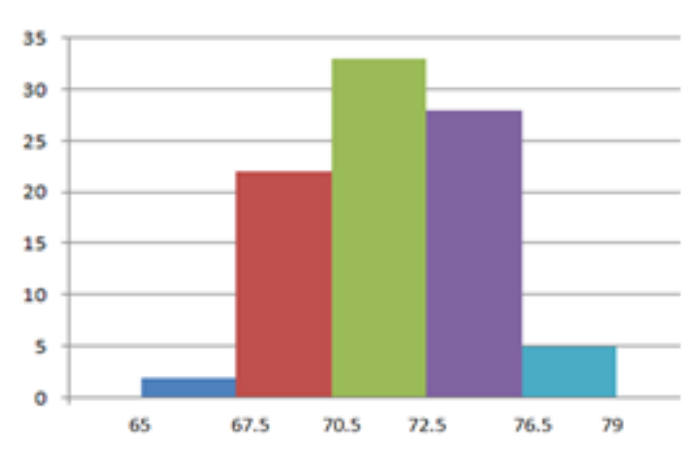

Gambar histogram data komitmen siswa 
Data hasil penelitian pengalaman prakerin dilakukan intrumen angket konsep diri dengan cara meyebarkan angket konsep diri. Data pengalaman prakerin seperti yang tampak pada gambar bawah

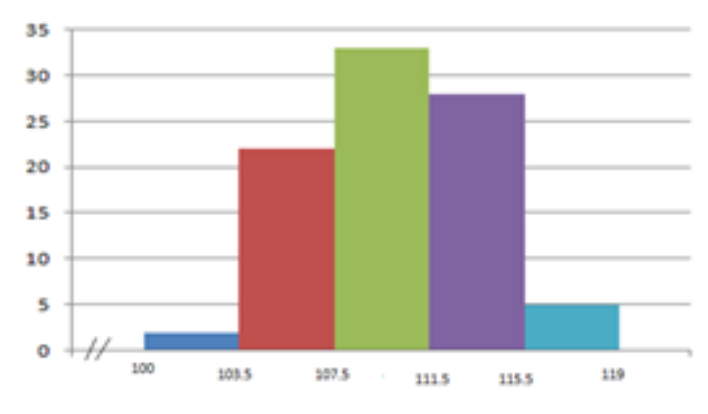

Gambar Histogram data kesiapan kerja

\section{Uji Hipotesis analis jalur}

Dalam penelitian ini, terdapat pengaruh terhadap suatu variabel yang tidak selamanya didominasi oleh satu variabel bebas atau beberapa variabel bebas secara langsung. Sering terjadi sifat pengaruh itu tidak langsung, yaitu melalui satu variabel yang paling dekat dengan variabel terikat (dependent variable). Variabel perantara (intervening variable) merupakan variabel yang menerima pengaruh dari banyak variabel bebas, yang kemudian variabel ini mempengaruhi secara langsung terhadap variabel terkait. Jika kita cermati secara teliti, tidak dimungkinkan akan menemukan hubungan antarvariabel bebas terhadap variabel terikat secara murni langsung. Untuk menganalisis pola hubungan yang tidak langsung itu diperlukan analisis khusus, yaitu analisis jalur (path analysis). Analisis jalur merupakan pengembangan analisis regresi ganda yang menguraikan besaran pengaruh dari variabel bebas terhadap variabel terikat secara tidak langsung.

Selanjutnya terdapat beberapa hal yang perlu diketahui dan dicermati dalam menerapkan analisis jalur dalam penelitian yang akan dibahas didalam penelitian ini. Seberapa besar pengalaman prakerin, konsep diri, komitmen siswa mempengaruhi kesiapan kerja bidang otomotif dan pengaruh yang paling besar terhadap kesiapan kerja.

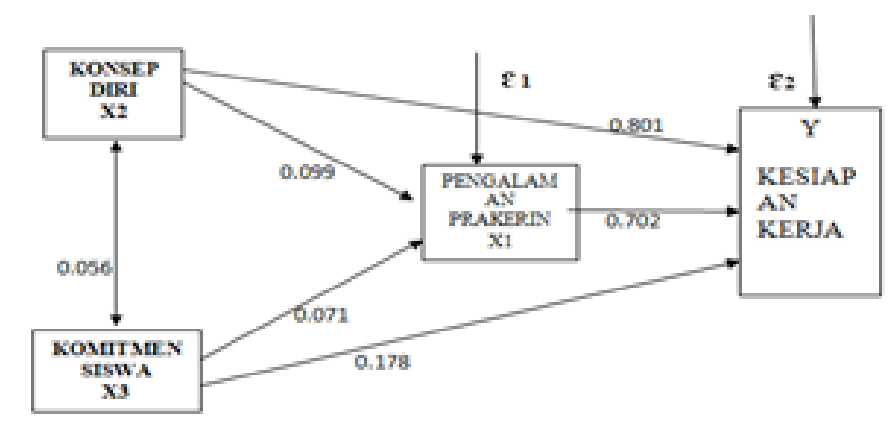

Gambar Model struktural analisis jalur

Persamaannya:

$\mathrm{X} 1=\rho \mathrm{X} 1 \mathrm{X} 2 \mathrm{X} 3+\rho \mathrm{X} 1 \mathrm{X} 3 \mathrm{X} 3+\varepsilon 1$ 
$\mathrm{Y}=\rho \mathrm{YX} 2 \mathrm{X} 2+\rho \mathrm{YX} 3 \mathrm{X} 3+\rho \mathrm{YX} 1 \mathrm{X} 1+\varepsilon 2$

\begin{tabular}{lll}
\hline Variabel & Pengalaman \\
Prakerin &
\end{tabular}

\begin{tabular}{lcccc}
\hline $\begin{array}{l}\text { Pengalaman } \\
\text { prakerin }\end{array}$ & 1.000 & 0.095 & 0.065 & 0.690 \\
\hline Kensep diri & 0.095 & 1.000 & 0,056 & 0.955 \\
\hline Komitmen siswa & 0.065 & 0.056 & 1.000 & 0.138 \\
\hline Kesiapan kerja & 0.690 & 0.655 & 0.138 & 1.000 \\
\hline
\end{tabular}

\section{Menguji koefisien jalur $\rho \mathrm{X} 1 \mathrm{X} 2$}

$\mathrm{H} 0: \rho \mathrm{X} 1 \mathrm{X} 2=\rho \mathrm{X} 1 \mathrm{X} 2=0$

Ha $: \rho \mathrm{X} 1 \mathrm{X} 2=\rho \mathrm{X} 1 \mathrm{X} 2 \neq 0$

H0 : Konsep diri dan komitmen siswa tidak berpengaruh secara simultan dan sinifikan terhadap pengalaman prakerin.

Ha : Konsep diri berpengaruh secara simultan dan sinifikan terhadap pengalaman prakerin.

Nilai $\mathrm{t}=0.930$ sig. $0.355>0.05 \mathrm{H} 0$ diterima Ha ditolak

\section{Menguji koefisien jalur $\rho \mathrm{X} 1 \mathrm{X3}$}

$\mathrm{H} 0: \rho \mathrm{X} 1 \mathrm{X} 3=\rho \mathrm{X} 1 \mathrm{X} 3=0$

Ha $: \rho \mathrm{X} 1 \mathrm{X} 3=\rho \mathrm{X} 1 \mathrm{X} 3 \neq 0$

H0 : Komitmen siswa tidak berpengaruh secara simultan dan sinifikan terhadap pengalaman prakerin.

Ha : Komitmen siswa berpengaruh secara simultan dan sinifikan terhadap pengalaman prakerin.

Nilai $\mathrm{t}=0.663$ sig. $0.509>0.05 \mathrm{H} 0$ diterima Ha ditolak 
$\mathrm{H} 0: \rho \mathrm{YX} 2=\rho \mathrm{YX} 2=0$

Ha $: \rho Y X 2=\rho Y X 2 \neq 0$

H0 : Konsep diri tidak berpengaruh secara simultan dan sinifikan terhadap kesiapan kerja.

Ha : Konsep diri berpengaruh secara simultan dan sinifikan terhadap kesiapan kerja.

Nilai $t=6.163$ sig. $0.045<0.05 \mathrm{H} 0$ ditolak Ha diterima

\section{Menguji koefisien jalur $\rho Y X 3$}

$\mathrm{H} 0: \rho \mathrm{YX} 3=\rho \mathrm{YX} 3=0$

Ha $: \rho Y X 3=\rho Y X 3 \neq 0$

H0 : Komitmen siswa tidak berpengaruh secara simultan dan sinifikan terhadap kesiapan kerja.

Ha : Komitmen siswa berpengaruh secara simultan dan sinifikan terhadap kesiapan kerja.

Nilai $\mathrm{t}=1.293$ sig. $0.045<0.05 \mathrm{H} 0$ ditolak Ha diterima

\section{Menguji koefisien jalur $\rho Y X 1$}

$\mathrm{H} 0: \rho \mathrm{YX} 1=\rho \mathrm{YX} 1=0$

$\mathrm{Ha}: \rho \mathrm{YX} 1=\rho \mathrm{X} 1 \mathrm{X} 1 \neq 0$

H0 : Pengalaman prakerin tidak berpengaruh secara simultan dan sinifikan terhadap kesiapan kerja.

Ha : Pengalaman prakerin berpengaruh secara simultan dan sinifikan terhadap kesiapan kerja.

Nilai $\mathrm{t}=3.776$ sig. $0.029<0.05 \mathrm{H} 0$ ditoloak Ha diterima

Dari hasil pengujian koefisien jalur diperoleh keterangan obyektif, bahwa koefisien jalur dari X1 ke Y, X2 ke Y dan X3 ke Y ketiga tiganya secara statistik adalah bermakna (thitung diatas ttabel dan p-value dibawah 0.05), sedangkan koefisien jalur dari X3 ke $\mathrm{Y}$ tidak bermakna (thitung dibawah ttabel dan p-value diatas 0.05). oleh karena itu proses akan diulang dengan mengeluarkan X3 dari model. Pengaruh antara pengalaman prakerin (X1), konsep diri (3) dan komitmen siswa (X3) mempunyai pengaruh positif terhadap kesiapan kerja (Y). Atas dasar ini yang telah diperbaiki ini diagram jalur menjadi sebuah diagram jalur pada gambar maka gambar struktural analisis jalur pada gambar

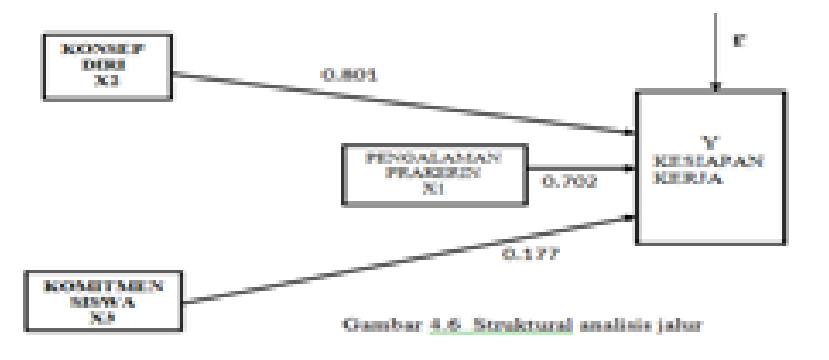

Persamaan struktural untuk diagram jalur diatas adalah:

$\mathrm{Y}=\rho \mathrm{YX} 1+\rho \mathrm{YX} 2+\rho \mathrm{YX} 3+\varepsilon$ 
$=0.702+0.801+0.178+0.968$

$=2.649$

Bahwa variabel X1 memiliki hasil thitung (3.776) dan X3 hasil t hitung 1.293 yang lebih kecil daripada hasil t hitung variabel X2 (6.163) jadi bisa dikatakan bahwa variabel X2 lebih besar pengaruhnya daripada X1 dan X3 terhadap variabel dependen. Kenyataannya dari hasil perhitungan pengaruh total variabel X2 terhadap variabel dependen adalah sebesar dibanding variabel lainnya.

\section{Penjelasan analisis jalur}

1. Konsep diri tidak berpengaruh secara simultan dan sinifikan terhadap pengalaman prakerin. Dari hasil pengujian koefisien jalur diperoleh keterangan obyektif, bahwa koefisien jalur dari variabel konsep diri (X2) kevariabel pengalaman praktik kerja industri (X1) secara statistik adalah tidak bermakna (thitung diatas ttabel dan $\mathrm{p}$-value diatas 0.05 ) dengan nilai: $\mathrm{t}=0.930$ sig. $0.355>0.05$ maka HO diterima Ha ditolak. Variabel konsep diri cenderung lebih berpenagruh langsung dengan variabel kesiapan kerja. Konsep diri, pengalaman praktik kerja industri dan komitmen siswa membuat siswa untuk membuat pertimbangan yang logis, mempunyai kemampuan dan kemauan untuk bekerja sama dengan orang lain, mampu mengendalikan diri, emosi, memilliki sikap kritis, mempunyai keberanian untuk menerima tanggung jawab secara individual, mempunyai kemampuan beradaptasi dengan lingkungan / perkembangan teknologi, dan mempunyai ambisi untuk maju serta berusaha mengikuti perkembangan bidang otomotif. Terbuktinya dapat memberikan informasi bahwa memasuki dunia kerja pengalaman praktik kerja industri, konsep diri, komitmen siswa secara bersama sama mempunyai pengaruh positif dan signifikan terhadap kesiapan kerja. Oleh karena itu pengalaman praktik kerja industri secara bersama sama harus diperhatikan untuk meningkatkan kesiapan kerja siswa. Semakin tinggi pengalaman praktik kerja industri, semakin tinggi konsep diri, semakin baik komitmen siswa yang dimiliki maka akan semakin tinggi pula kesiapan kerja siswa dalam menghadapi dunia kerja.

2. Komitmen siswa tidak berpengaruh secara simultan dan sinifikan terhadap pengalaman praktik kerja industri. Dibuktikan dengan nilai $\mathrm{t}=0.663$ sig $0.509>0.05 \mathrm{H} 0$ diterima Ha ditolak. Komitmen siswa membuat siswa untuk membuat pertimbangan yang logis, mempunyai kemampuan dan kemauan untuk bekerja sama dengan orang lain, mampu mengendalikan diri,emosi, memilliki sikap kritis, mempunyai keberanian untuk menerima tanggung jawab secara individual, mempunyai kemampuan beradaptasi dengan lingkungan atau perkembangan teknologi, dan mempunyai ambisi untuk maju serta berusaha mengikuti perkembangan bidang otomotif. Terbuktinya dapat memberikan informasi bahwa memasuki dunia kerja pengalaman praktik kerja industri, konsep diri, komitmen siswa secara bersama sama mempunyai pengaruh positif dan signifikan terhadap kesiapan kerja. Oleh karena itu pengalaman praktik kerja industri secara bersama sama harus diperhatikan untuk meningkatkan kesiapan kerja siswa. Semakin tinggi pengalaman praktik kerja industri, semakin tinggi konsep diri, semakin baik komitmen siswa yang dimiliki maka akan semakin tinggi pula kesiapan kerja siswa dalam menghadapi dunia kerja.

3. Bahwa variabel X1 memiliki hasil thitung (3.776) dan X3 hasil t hitung 1.293 yang lebih kecil daripada hasil thitung variabel X2 (6.163) jadi bisa dikatakan bahwa variabel X2 lebih besar pengaruhnya daripada X1 dan X3 terhadap variabel dependen. Kenyataannya dari hasil perhitungan pengaruh total variabel X2 terhadap variabel dependen adalah sebesar dibanding variabel lainnya. Hubungan antara konsep diri dengan kesiapan kerja tidak memiliki pola hubungan tidak langsung, akan tetapi memiliki pola hubungan langsung yang sinifikan $(\rho Y . X 2=$ 0,801). Meskipun hubungan pengalaman prakerin dengan kesiapan kerja namun derajat hubungannya tidak paling tinggi dibangdingkan dengan variabel variabel lainnya. Besarnya penaruh yang diterima $\mathrm{Y}$ dari $\mathrm{X} 2$ adalah $47.65 \%$.

\section{Hasil hipotesis}

1.Pengaruh antara pengalaman prakerin dengan kesiapan kerja tidak memiliki pola hubungan tidak langsung, akan tetapi memiliki pola hubungan langsung yang sinifikan $(\rho Y . X 1=0,702)$. 
Meskipun hubungan pengalaman prakerin dengan kesiapan kerja namun derajat hubungannya tidak paling tinggi dibangdingkan dengan variabel variabel lainnya. Besarnya penaruh yang diterima Y dari X1 adalah $41.80 \%$.

2.Pengaruh antara konsep diri dengan kesiapan kerja tidak memiliki pola hubungan tidak langsung, akan tetapi memiliki pola hubungan langsung yang sinifikan $(\rho Y . X 2=0,801)$. Meskipun hubungan pengalaman prakerin dengan kesiapan kerja namun derajat hubungannya tidak paling tinggi dibangdingkan dengan variabel variabel lainnya. Besarnya penaruh yang diterima Y dari X2 adalah $47.65 \%$.

3.Pengaruh antara komitmen siswa dengan kesiapan kerja tidak memiliki pola hubungan tidak langsung, akan tetapi memiliki pola hubungan langsung yang sinifikan ( $\rho Y . X 3=0,178)$. Meskipun hubungan komitmen siswa dengan kesiapan kerja namun derajat hubungannya tidak paling rendah dibangdingkan dengan variabel variabel lainnya. Besarnya pengaruh yang diterima Y dari X3 adalah $10.55 \%$.

\section{Kesimpulan}

Berdasarkan hasil pengujian dan diskusi hasil penelitian, maka dapat ditarik kesimpulan sebagai berikut.

1.Konsep diri tidak berpengaruh secara simultan dan sinifikan terhadap pengalaman praktik kerja industri, secara statistik adalah tidak bermakna (thitung diatas ttabel dan p-value diatas 0.05 ) dengan nilai: $\mathrm{t}=0.930$ sig. $0.355>0.05$ maka $\mathrm{H} 0$ diterima Ha ditolak.

2.Komitmen siswa tidak berpengaruh secara simultan dan sinifikan terhadap pengalaman praktik kerja industri. Dibuktikan dengan nilai $\mathrm{t}=0.663 \mathrm{sig} 0.509>0.05 \mathrm{H} 0$ diterima Ha ditolak.

3.Konsep diri berpengaruh secara simultan dan sinifikan terhadap kesiapan kerja bidang otomotif siswa sekolah menengah kejuruan di Kediri. Nilai $t=6.163$ sig. $0.045<0.05$ H0 ditolak Ha diterima sehingga konsep diri berpengaruh secara simultan dan sinifikan terhadap kesiapan kerja.

4.Komitmen siswa berpengaruh secara simultan dan sinifikan terhadap kesiapan kerja bibang otomotif siswa sekolah menengah kejuruan di Kediri. Nilai $t=1.293$ sig. $0.045<0.05$ H0 ditolak Ha diterima

5.Pengalaman praktik kerja industri berpengaruh secara simultan dan sinifikan terhadap kesiapan kerja bibang otomotif siswa sekolah menengah kejuruan di Kediri. Nilai $t=3.776$ sig. $0.029<0.05 \mathrm{H} 0$ ditoloak Ha diterima

6.Variabel konsep diri merupakan variabel yang paling berpengaruh secara simultan dan sinifikan terhadap kesiapan kerja bidang otomotif siswa sekolah menengah kejuruan di Kediri. Variabel X1 memiliki hasil t hitung (3.776) dan X3 hasil t hitung 1.293 yang lebih kecil daripada hasil $t$ hitung variabel X2 (6.163) jadi bisa dikatakan bahwa variabel X2 lebih besar pengaruhnya daripada X1 dan $\mathrm{X} 3$ terhadap variabel dependen

\section{Daftar Pustaka}

[1] N. W. A. Majid and P. Sudira, "Proses perolehan kompetensi TIK melalui program praktik industri siswa SMKN 2 Pengasih Kulon Progo," J. Pendidik. Vokasi, vol. 7, no. 1, p. 14, 2017.

[2] P. B. Herlandy, E. Ismanto, M. Novalia, R. Al Rian, N. Effendi, and D. Hamka, "Factors that Contribute to the Achievement of Vocational Competencies of Vocational School Students in Pekanbaru," in International Conference of CELSciTech 2019-Social Sciences and Humanities track (ICCELST-SS 2019), 2019, pp. 40-45.

[3] D. Fitri Perwitasari, "Hubungan Fasilitas Praktikum TKJ di Sekolah, Kesesuaian 
Tempat Prakerin, dan Kompetensi TKJ Siswa dengan Hasil Uji Kompetensi Keahlian," pp. 425-430, 2011.

[4] P. Sudira, "Praksis Pendidikan Kejuruan Indonesia diantara Mazab John Dewey dan Charles Prosser," in Seminar Pendidikan Vokasi sebagai Disiplin Keilmuan, 2013.

[5] A. Arfandi and O. Sampebua, "KESIAPAN PELAKSANAAN PRAKTIK KERJA INDUSTRI PROGRAM STUDI KEAHLIAN TEKNIK BANGUNAN DI KOTA MAKASSAR," J. Cakrawala Pendidik., 2016.

[6] H. Jaya, "Pengembangan Laboratorium Virtual untuk Kegiatan Paraktikum dan Memfasilitasi Pendidikan Karakter di SMK," J. Pendidik. Vokasi, pp. 81-90, 2013.

[7] A. A. Priyatama and S. Sukardi, "Profil kompetensi siswa SMK kompetensi keahlian teknik kendaraan ringan di Kota Pekalongan,” J. Pendidik. Vokasi, 2013.

[8] S. Arikunto, "Prosedur Penelitian Tindakan Kelas," Bumi Aksara, 2006. 